\title{
10. Public policy on career education, information, advice and guidance: developments in the United Kingdom and Norway
}

\section{Christine Lewis and Ida Tolgensbakk}

\section{INTRODUCTION}

This chapter considers the role of career education, information, advice and guidance (CEIAG) services. On the one hand, it looks at public policy in England, where such services have a 20-year record of instability; on the other, the chapter considers Norway, where CEIAG services are beginning a new era in supporting young people's entry into employment. As well as examining how effectively CEIAG policy and practice are framed in the two countries, we identify barriers to delivery and explore whether Norway can learn lessons from England in a process of policy transfer. The chapter is informed by NEGOTIATE research findings ${ }^{1}$ and by the voices of informants who experienced unemployment in their youth.

\section{CAREER GUIDANCE}

Career guidance has been defined as 'services and activities intended to assist individuals, of any age and at any point throughout their lives, to make educational, training and occupational choices and to manage their careers' (OECD, 2004: 19). Three key purposes of the function have been identified: supporting informed choices about work and learning; effective management of transitions; and helping people with career management skills to 'develop resilience in the face of constant change' (Higginbotham and Hughes, 2006: 1).

1 NEGOTIATE: Overcoming early job insecurity in Europe. See https://negotiate-research. eu. 
Career guidance has its roots in the early 1900s and is often described as concomitant with industrialization (Savickas, 2003). Part of this legacy is that services have been oriented towards vocational training and young people not entering higher education. Economic transformations, such as deindustrialization and the shift of manufacturing to Asia, have changed the labour market in many Western countries and have reduced job supply based on local industry. Now economic hopes are pinned on the 'knowledge-based economy' (Drucker, 1969) - an expression coined to describe trends in advanced economies towards greater dependence on knowledge, information and high skill levels.

The move towards a knowledge economy and high levels of participation in higher education engenders new questions about the link between education and training and future employment. The more dynamic the labour market, the greater the challenge in ensuring that job demand and supply match, which is a key function of career guidance. As well as imparting information and career skills, services are increasingly focused on groups with particular needs and on the provision of individualized support. Policies focused on young people who are not in employment, education or training (NEETs) have moved up the agenda globally.

CEIAG services and their role in helping individuals to find a place in the labour market are of international concern, as demonstrated in a coordinated review of reports from the Organisation for Economic Co-operation and Development (OECD), the European Commission and the World Bank (Watts and Sultana, 2004). Covering 37 countries, the review authors assert that in all of them career guidance is regarded as a public good for learning, the labour market and social equity (Watts and Sultana, 2004: 105). There have been annual international symposia concerned with CEIAG since 1999, and 2004 saw the establishment of the International Centre for Career Development and Public Policy (ICCDPP), which is committed to sharing examples of effective national career development strategies, legislation and policy evaluation. The European Lifelong Guidance Policy Network (ELGPN) followed in 2007, founded to assist European countries and the European Commission in policy development and cooperation (ELGPN, 2017).

Although the need for support from outside agencies for young people transitioning to employment was echoed across countries in the NEGOTIATE research, we chose to focus on CEIAG services in England and Norway for a number of reasons. Both countries acknowledge the pressing need to develop policy for the career development and guidance sector. Reporting to the ICCDPP on behalf of Norway, Bakke et al. (2017: 2) suggest that 'we are now at a crucial crossroads where decisions must be made'. Meanwhile, in the United Kingdom a study of career guidance 
policy has asserted that 'the need to take sustained action to improve career guidance is more pressing than ever' (Holman, 2014: 3). This statement sits on a 20-year policy effort aimed at establishing effective CEIAG services, which, we argue, have yet to take root successfully. We attempt to identify why this is the case, given that CEIAG policy is developed in the wake of economic change. In particular, we ask:

- How are good CEIAG policy and practice framed in the United Kingdom and Norway?

- What barriers do CEIAG services face?

- Are there CEIAG policy lessons that can be transferred from the United Kingdom to Norway?

\section{THE IMPORTANCE OF CEIAG}

The underlying assumption in our study is that CEIAG services have a critical role to play in the avoidance of early job insecurity. The proposition that CEIAG is linked to health, education and welfare agendas, as well as to economic success, provokes little controversy. Its central role in social inclusion and social mobility agendas is widely acknowledged (Bridge Group, 2011; Hughes, 2011; Social Mobility and Child Poverty Commission, 2013). Poor CEIAG has often been blamed when these agendas are threatened (Hooley et al., 2014). ELGPN (2015: 40) emphasizes the strong link between career guidance policy and the Europe 2020 strategy goals of full employment, reduced early school-leaving, increased higher qualification attainment, and helping people out of poverty and social exclusion.

The ELGPN commissioned Concept Notes that address: (1) Flexicurity; (2) Youth unemployment; (3) Career management skills; (4) Youth Guarantee; (5) Work-based learning; and (6) Early school-leaving (ELGPN, 2015). In these notes the key role of CEIAG policy is identified. Note 1 focuses on the relationship between flexibility and security at work and identifies the need to 'insert' career guidance into this policy discourse (Sultana, 2012: 9). It recommends that job flexibility should be concomitant with the employability of the individual, guaranteed through employer and state investment in education, training and CEIAG, which it says is 'inextricable from the notion of security' (Sultana, 2012: 10).

After a comprehensive review of EU member-state guidance policies, it is concluded in Concept Note no. 4 that 'without lifelong guidance, the Youth Guarantee could merely provide a temporary diversion to keep young people off the streets; with lifelong guidance, it could become a 
springboard to a better future' (Borbély-Pecze and Hutchinson, 2013). In Concept Note no. 6 a comprehensive career education programme through school is described as 'the backbone' of preventing early school-leaving (Oomen and Plant, 2014: 14), reiterating the importance of CEIAG policy.

\section{METHOD}

Although career guidance is a lifelong requirement that national policies must address, our focus is on services for young people who are in transition from school to higher or further education, or to employment or training, who might be facing unemployment, underemployment or a lifetime of precarious working. For the present discussion, we draw on data from NEGOTIATE life-course interviews from the United Kingdom and Norway (for details of the qualitative data collection, see Hvinden et al., Chapter 1 this volume). This information comes from a limited number of informants in only two countries in the NEGOTIATE project. It is also the case that the interviewees were selected on the basis of their experience of unemployment and subsequent underemployment. That does not invalidate the details of their personal experience or the flavour that they provide of the barriers that young people may face and the related support that is required. A strength of these data is that they span three age-related cohorts (born 1950-55, 1970-75 and 1990-95), providing some longitudinal comparison and insight into how the changing policy regimes have given support during the vulnerable transition between education and employment. Individual life-course interviews are referenced by pseudonym and decade of birth. The interview data show quite clearly that there is an unmet need for support, with many interviewees across Europe stating that some sort of career guidance would have eased their transition from education to employment. We suggest that CEIAG services and their delivery through effective national policy and practice would go towards meeting this need.

There was no specific question in the NEGOTIATE life-course interviews about CEIAG services, rather a more general question about help and support during transition from school into a 'meaningful job', defined in terms of financial reward, personal development and fulfilment. All interviewees were asked questions about how they were helped, for instance, by governmental institutions, non-governmental bodies or social circles. They were then asked whether they had recommendations for future policy changes that they believed would help young unemployed individuals experiencing similar hardships to themselves. Some of our interviewees spoke directly of CEIAG measures, but most 
did so indirectly, recounting that they should have had a better plan but that they had no idea what they wanted to do after school. Importantly, when trying to convey what they believed would have been helpful for themselves and others, a recurring statement across our qualitative data was that good career guidance would make a significant difference. In the following pages we will outline CEIAG policies in England and Norway and their development over time in the context of how good practice has been framed. We consider England's chequered history of CEIAG policy formation and also the situation in Norway, where there have been recent initiatives to develop these services. Beforehand, however, we present our qualitative findings and describe the inspiration for this chapter.

\section{IN THE WORDS OF UK AND NORWEGIAN INTERVIEWEES}

The interviewee from the United Kingdom we have named Joseph (UK 02 M 1950) said that in his youth there were jobs about, but not necessarily those of one's choice. As a working-class young man, he said that thoughts of pursuing a professional career, as he did later in life, 'were a million miles away'. The quality of available advice was also called into question by a Norwegian interviewee in the same cohort: Paulus (NO 06 M 1950) reported an unstable work history, referring to early exam failure and his lack of awareness at the time that he could have accessed higher education through a prior-learning scheme. Another older Norwegian interviewee, Elin (NO 13 F 1950), described her drift into marriage and motherhood in her mid-20s and life-scarring decisions that she had made. When trying to find work later, Elin's only support had come from the employment service, where she encountered various caseworkers, some of whom were ill-informed about or unaware of major measures such as subsidized jobs. She recalled a positive experience with a caseworker who was 'into seeing people as a resource and not a problem, she had just finished her education, really energetic and nice, and she asked me questions to really get to know me, we really clicked'. Summing up, Elin stressed that the most important factor in gaining good employment was having a career plan as a young adult. Elin's experience was echoed by Tina from the oldest UK cohort (UK $04 \mathrm{~F}$ 1950), who expressed frustration at protracted routes into meaningful work. Tina's experience led her to assert that careers advice was the most important element in supporting young people's transitions: 
If I had the opportunity now in this country, I would teach career lessons in schools, because I think it's so important to give kids that focus of like, 'What do you want to do? Let's look at it now, not when you're 25 or 30 .'

Those in the oldest cohort were also aware of later CEIAG services, in some cases through their children. Mo (UK 01 F 1950) contrasted her son's experience to her own:

Careers advice I think is huge because my son would never have got the job he has got now and qualified, because he is dyslexic. He would never have become a carpenter/joiner [without] the career adviser. I think careers advice is huge. I would probably have gone into nursing, because somebody along that line would have given me the confidence to do it.

The middle cohort of interviewees - born in the 1970s - does not reflect any particular improvement in CEIAG services. There were several comments in the UK group about the rise in unemployment at the time and migration to London or other big cities in the hope of finding work that did not exist. Jade (UK 10 F 1970) described feeling lost:

I had a lot of little jobs - literally from credit control to a flower shop to an engineering company. I was just tumbling into different jobs. . .I think counselling in schools would be amazing, because kids are lost sometimes. . .I haven't got a career. I built up that legal secretary side, but it's done me no favours really. I'm still floating around.

A Norwegian interviewee in this cohort, Rigmor (NO 15 F 1970), described dropping out of school and later joining a job club which referred her to a course where she could finish her school-leaving diploma: 'It was a really intensive six months with learning directed towards the final exam. It was a really good measure! I just wish it had come a couple of years earlier for me.' Rigmor recounted how she had asked the employment service for advice on what were her best choices, but that there was no advice available. As jobs got fewer, she felt that her broken work record was a problem: 'It matters, of course, because when there's a lot to choose from, you don't choose the one with holes in her CV.' Rigmor expressed sympathy with the overworked caseworkers at the local labour and welfare office, who were doing their best trying to accommodate the needs of everyone from all walks of life. However, she also firmly stressed that the help given to her had been inadequate. Another Norwegian interviewee in this cohort, Kristina (NO 18 F 1970), was less generous in describing the employment office, saying:

...they just sit there, managing people and hosting classes. They don't help people into employment. That's my experience anyway. 
Even interviewees in the youngest cohort - born in the 1990s - said that they had experienced inadequate career guidance. Anne (NO 08 F 1990), a Norwegian interviewee who was still trying to find her niche, described discouragement from parents and the school counsellor, who had said that pursuing her interest in mechanics would be gender inappropriate, so she was directed into health and social care. In the United Kingdom's youngest cohort there was some experience of a now defunct service (see Section 7 on CEIAG policy in the United Kingdom), where young people could go for advice and guidance. Sadiqi (UK 22 M 1990) demonstrated this when he recounted:

I went to the Connexions a few times and the Citizens Advice Bureau to ask what stuff to do. Because that was the only place that I knew of.

There were comments in the youngest cohort about the problem of jobseeking with no work experience. Jarle (NO 19 M 1990), a Norwegian interviewee, said that:

Experience should be more available, you need experience to get a job, it's a vicious circle, those without experience don't get a job.

He had not been able to get any help from public agencies, but he managed to find fixed-term positions on his own. Kylie (UK 23 F 1990), a UK interviewee, complained of having little support because she had rejected the academic route, despite gaining four A-levels (ISCED level 3). The only advice Kylie claims to have been given was to apply to university, but she did not want a career in the subjects that she had studied. She now felt that having a degree had become a 'staple in a job', regardless of the subject, and found the subsequent six months of unemployment after school to be demoralizing and depressing. Kylie also emphasized the need for work-ready skills: 'without any (employability) skills as well, trying to find a job was quite hard'. It is evident that the young jobseekers we interviewed wanted better CEIAG from public agencies. For instance, UK interviewee Josh (UK 25 M 1990) repeated several times that he felt unsupported in trying to increase his employability. When asked how public policy should change, his message to government was, 'just give a bit more effort in helping people'.

Across ages in both countries, interviewees with physical and mental illness or disability appeared to receive little helpful intervention, although this was not always the case. Lulu (UK 28 F 1990) suffered mental health problems and between the ages of 20 and 23 was supported by a personal careers adviser. She stated that she could not have progressed without the 
adviser, who helped her into voluntary work and also with welfare and benefit claims. Amongst the Norwegian interviewees there were several individuals with physical or mental disability issues, and some of them recount stories similar to Marit's (NO $10 \mathrm{~F}$ 1990). She described her experience on an apprenticeship that was not monitored by the employer or her school and from which she was sacked because she could not cope. She recalled:

And I was worried, what do I do now, out of school, out in working life on my own? What do I do?

Others reported inadequate support, starting at school. A Norwegian interviewee in the middle cohort, Nidar (NO 16 M 1970), said that his dyslexia had not been diagnosed until much later in life. He said that his teachers called him 'stupid' and that he was advised to take a vocational route. Another Norwegian interviewee, Martin (NO 09 M 1990), described different job training offered to him by the employment service, coaches and caseworkers, but felt that there was little available to match him to a job at his mental capability level. He said: 'I had to tell my story over and over without it making any difference'. For him, the system of different departments and services not working well together had added to his troubles. The need for coordinated services was echoed by Mai (NO 07 F 1950), who called on doctors and therapists for support, and by Astrid (NO 04 F 1990), who needed rehabilitation services to intervene with the school and employment services to explain her challenges.

CEIAG is not a stand-alone magic bullet but part of the policy complex that should be in place to help young people avoid unemployment and precarious working. We now consider what good CEIAG policy and practice might look like.

\section{GOOD PRACTICE IN CEIAG SERVICES}

CEIAG policy is sometimes characterized by disjuncture between allage career services and those that are more focused on young people in transition from school to adult working lives. Another distinction is made between career education and advice and guidance services that take a more proactive, nurturing approach to the individual. Key factors for effective delivery have been identified (Bakke et al., 2017; Holman, 2014; Hughes, 2017) as competent stakeholder partnerships in an overarching strategy that provides clear accountabilities and generates policy ownership and consistency of provision monitored to meet quality standards 
(McQuaid, 2010). In addition, the need for qualified careers staff and training for leaders and other staff is acknowledged. Moreover, it has been recommended that these services should be considered within the broader context of careers education and the wider school curriculum (McCrone et al., 2010: 31-2). Acknowledging the psychological pressure of leaving school and moving to a more adult phase of life, Hughes and Borbély-Pecze (2012: 12) call for effective preparation - accessible to all young people for successful working. They write that 'perceived abandonment' should be ameliorated by visible and accessible career services, which should also meet the needs of sub-groups, comprised of those facing particular disadvantage. The challenge is to have an inclusive CEIAG service that also caters adequately for young people who require individualized support.

The search for good CEIAG practice is being carried out worldwide. The Gatsby Foundation, a UK-based charity focused on economic development, produced an international study of good career guidance practice involving a comprehensive literature review and visits to Canada, Finland, Germany, Hong Kong, the Netherlands and Ireland (Holman, 2014). The report identified positive features in national case studies, highlighting the effective and stable CEIAG services in Finland. Eight benchmarks of good practice were developed from the evidence (Holman, 2014: 7):

- Embedded, stable careers programme;

- Learning from career and labour market information (supported by informed advisers);

- Addressing the needs of every student at different stages (equality and diversity mindfulness throughout);

- Linking curriculum learning to career options;

- Encounters with employers and employees;

- Encounters with colleges and universities;

- Experience of workplaces;

- Personal, face-to-face guidance to meet individual needs (school staff member or external adviser trained to appropriate level).

These benchmarks are promoted by the United Kingdom's Career Management Quality Alliance (consisting of four major interest groups) in their policy strategy to deliver career management and employability skills and personal guidance. The Alliance also calls for a statutory framework; national and local leadership; coordinated partnership; staff professionalism; sufficient resources; and CEIAG policy stability (Career Management Quality Alliance, 2017). The importance of CEIAG, enshrined in law and reflected in resource commitment, national and local governance, and the quality of career practitioners, emerges as a common theme in good 
practice evaluation. In a report focused on career guidance reforms in Norway, Bakke et al. (2017: 9) identify what the success factors in reform will be:

- Policy: National skills strategies form the basis for regional strategies and implementation of coordinated plans in local practical collaboration, of which career services are an integral part. Resources and funding are realistic.

- Content and type of services: Framework, standards of quality and of staff competencies are agreed on nationally and regionally and followed up in all sectors.

- Delivery methods: Access to a diversity of career services being unrolled within the framework and missions of the sectors, together meeting the OECD definition of career guidance (OECD, 2004). Increased development of ICT-based career services will increase the access and utilization of career services for the majority of citizens. In the Norwegian labour and welfare administration (NAV) automating processes project, conversion of ICT support and communication channels will simplify the system of following up users, enabling dynamic guidance with enhanced user involvement.

It is envisaged that online services will increase user involvement and facilitate follow-up of individuals. The concept of user involvement is championed by Hughes and Borbély-Pecze (2012: 10), who suggest that users should help shape services through quality and impact feedback, arguing that there is an 'urgent imperative' to provide effective CEIAG quality assurance systems and accountability frameworks.

There are warnings about reliance on digital technologies in CEIAG services, which is a growing feature of good practice advice. Hooley et al. (2010, 2015: 65) provide 14 country case studies, concluding that the penetration of web and mobile technologies is very high in England, although there are 'continuing issues with both digital exclusion and low levels of digital literacy amongst some elements of the population'. Polarization is recognized between online service advocates and those who argue for face-to-face services. Hooley et al. promote a 'blended' approach in which face-to-face and digital services are brought together in an integrated strategy (Hooley et al., 2015: 40) - an approach reflected in Norwegian CEIAG ambitions. CEIAG policies have been in place for many decades in the United Kingdom, with varying approaches and mixed results. This history provides lessons that might be learned by Norway in their policy reform efforts, which might in turn influence English CEIAG services. 


\section{CEIAG POLICY IN THE UNITED KINGDOM}

The devolved nations of the United Kingdom are responsible for their own career guidance strategies, so we focus on CEIAG services in England, where the qualitative interviews in the NEGOTIATE project took place. Rachel Mulvey (2006: 14) provides a history of career guidance in England, beginning with statutory requirements in 1902 aimed at guiding young people into employment. In 1948 a Youth Employment Service was established that developed into a Careers Service, which in 1973 mandated a partnership model in which schools, colleges and local authorities were to provide youth career guidance. The CEIAG partnership model, praised by the OECD (2004), went into decline in the 1990s (Hooley et al., 2014). In 1993, privatization of statutory CEIAG provision was announced and the 'discipline of the market' was applied (Mulvey, 2006: 15-16).

After the 1997 general election, the incoming Labour government reorganized CEIAG services, placing greater emphasis on disadvantaged young people, particularly those in danger of becoming NEET. Following a report by the Social Exclusion Unit (1999), the Connexions service was established to provide '[i]nformation, advice, support and guidance services, including outreach facilities, to connect and reconnect young people with learning' (Ashworth et al., 2001: 2). Multi-disciplinary Connexions partnerships and the personal adviser role were introduced in 2001, with a broad remit to provide advice to all young people aged between 13 and 19 (Dobson et al., 2003: 88). The balance in career guidance was said to have changed as those who had traditionally been under-supported and those who were most likely to drop out became the focus of provision (Coldwell et al., 2005: 1). Connexions partnerships were part of the strategy of advice and guidance to young people, which required major restructuring (Department for Education and Skills, 2003).

Maguire and Maguire (2004: iv) noted that 'the ability of Connexions Services to provide the required level of support will clearly be dependent on their having adequate resources, notably in terms of sufficient Personal Advisers'. The National Audit Office (2004: 25) estimated that 15500 personal advisers would be required, although four years into the service only 7722 were in post. Government rhetoric on the importance of CEIAG's vital role had not averted 'a distinct lack of cohesion and consistency of approach' (Higginbotham and Hughes, 2006: 1). Since 2010, Connexions services have disappeared and the responsibility for CEIAG for young people has been delegated to schools, supported by a National Careers Service (primarily online) and a Careers and Enterprise Company.

Evaluation of current CEIAG policy in England has been highly critical. The inspectorate Ofsted found that only one in five schools was 
fulfilling schools' career guidance statutory duties (Ofsted, 2013). A parliamentary committee stated that it was 'very disappointed that careers advice and guidance is still so poor in so many schools' (Sub-Committee on Education, Skills and the Economy, 2016a: 29). This committee recommended, amongst other things, that 'the unruly and complex web of organisations, providers and websites' be untangled. Government rejection of the report (Sub-Committee on Education, Skills and the Economy, 2016b) drew a reaction from the committee expressing regret that the government was 'burying its head in the sand' about the poor quality of career guidance (UK Parliament, 2016). In February 2017 the UK government updated its guidance to schools in England on their statutory duty to provide career guidance (Department for Education, 2017). This 'statutory guidance' is a charter for good CEIAG practice, without any indication of how schools might resource or manage it, leaving a gaping hole between rhetoric and reality. We now consider CEIAG in Norway before discussing the lessons that the country can learn from England's chequered policy history.

\section{CEIAG POLICY IN NORWAY}

CEIAG services in Norway have been based on both education and the labour market, with advice and guidance counselling provided in schools, colleges and universities as well as in regional career centres and local employment centres. Focused on vocational guidance, as enshrined in the 1947 Employment Act, partnerships between guidance counsellors at school and vocational counsellors in the employment service were stable until the 1980s, whereas there have been various policy changes in the guidance role of the latter since then. The 1998 Education Act requires CEIAG in schools, which is described as a gradual and long-term process with individual rights to career, personal and emotional support.

By 2002 the OECD was describing Norway's guidance policy as unclearly articulated with no coherent strategy (OECD, 2002: 5). It noted that 'apparent growth of pupils' personal and social problems' impacted on guidance services, subsequently leading to a trial split between career guidance and personal counselling (OECD, 2002: 13). Local follow-up services, which provided a safety net for early school leavers (aged 16-21), had been introduced in 1994 with a focus on those in the NEET group. According to NEGOTIATE research, this policy has been reviewed and updated several times, reducing the number of young people who were out of reach from 23 per cent in 2010 to 5 per cent in 2014-15 thanks to more active use of the local NAV offices, school counsellors and youth outreach 
teams. Despite this progress, it has been suggested that there is great variation in the levels of support on offer and that cooperation between different services is still inadequate (NEGOTIATE, 2017: 26-7).

New challenges have increased the focus on career guidance and its integral relationship with the skills agenda and the labour market. In 2008 state-funded regional stakeholder partnerships were established in the 19 counties of Norway, mostly with career centres (Euroguidance, 2014). The Norwegian economy is facing change in the short term because of lower oil prices and in the longer term as oil stocks deplete and a greener economy is required. The labour market is also transforming as a result of technological change, and there is a need for new skills that require a review of education in order to maintain its relevance to employability. There are also projected skill shortages in areas such as nursing, care work, and technical and scientific fields, which 'will require renewed efforts to better inform students' educational choices and provide appropriate incentives' (OECD, 2014: 2).

Norway has embarked on a number of initiatives to improve CEIAG. The adequacy of professional practice in career guidance in meeting new challenges has received attention. This has been particularly evident in services to pupils with migrant backgrounds (see, e.g., Spernes 2014, who found that young people from migrant families reported little or no career guidance). Since 2014 training courses for employment service staff, delivered in the Norwegian NAV system and university colleges, have been developed with the aim of strengthening staff competences in work-directed guidance. In higher education, where there is a tradition of autonomy, the government has provided targeted funding for a new master's programme, 'thus indicating the importance of upskilling of career guidance practitioners in Norway' (Bakke et al., 2017: 10). The National Unit for Lifelong Guidance in Skills Norway was invited to contribute to the programme's development phase, and dialogue with stakeholders has followed. A module on career guidance is also being added to a new Master's degree in teacher education.

Developments in career guidance education and training are running in parallel with a National Skills Policy Strategy agreed by five government ministries in February 2017, and trials of interministerial coordination have begun. A 2016 White Paper described measures aimed at increasing access and reducing obstacles to career guidance, such as limited options for transitions between general education and vocational education and training. These include a new compulsory programme in career development in secondary schools ('Educational Choice'), which includes elements of career learning and career management skills; career centres in almost every county in Norway; and access to free professional career 
services. The plan is to strengthen contact between career practitioners and labour market sectors, with collaboration on staff training and partnerships between central stakeholders in every county. There is a focus on cross-sectoral cooperation and coordination about groups at risk at a political and administrative level, especially young people and refugees (Bakke et al., 2017: 5-7).

Norwegian government and academic advisers interviewed by the NEGOTIATE team identified further progress that needs to be made: strengthening cooperation between career guidance stakeholders; widening access to services in schools and higher education; and the professional development of career guidance practitioners and teachers involved in career learning programmes. Bakke et al. (2017: 7-8) have identified the need for higher-quality advice with better trained staff and further development of ICT-based guidance services. They argue that Norway's labour and welfare administration system needs restructuring so as to provide stronger local assessments and evidence-based improvements, as well as individualized services, adapted follow-up methodology and labour market schemes such as 'Place then Train'. Simplification of the ICT-based guidance tools and enhanced user involvement are planned so as to enable more dynamic guidance, putting the user in the 'driver's seat'. Hooley et al. (2015:3) believe that 'the relative newness of career guidance in Norway combined with strong political support for the activity offers the country an exciting opportunity to build a world class system'.

\section{DISCUSSION}

In the NEGOTIATE research discussed here, the UK interviewees reported experiences of unemployment, temporary contracts, agency work, zero-hours contracts and low-quality jobs in their early working life, with little support from outside agencies. In the Norwegian findings, a deficit was reported in appropriate help from Norwegian NAV offices; personalized strategies and planning; and education or career supervision from parents and teachers (NEGOTIATE, 2017). A lack of help and support emerged as a common theme, whether it was described as careers advice, counselling, mentoring or coaching. There was little enthusiasm for the support provided by the employment service in either country. NEGOTIATE interviewees reflect the variability of experience of education, employment or career guidance services in providing support to young people en route to employment. Views were expressed that a poor and uncertain entry into a competitive job market may cause lifetime scarring. 
CEIAG policy instability is said to have begun in the United Kingdom in the 1990s with the privatization of the service and little subsequent evaluation, leading Tony Watts (1996: 389) to conclude that 'the notion that the public interest in guidance as a market-maker could be adequately delivered by the market in guidance began to look seriously flawed'. According to Watts (2008), the Connexions companies contributed to the decline of the partnership model of CEIAG delivery. The creation of Connexions partnerships was said to lead to confusion about what was on offer, to whom and for what reason (Mulvey, 2006: 19). Nonetheless, several of our interviewees reported positively on the service, which never received adequate resources or more than half the required number of personal advisers. The balance between universal and targeted guidance for young people was said to stretch resources, and several studies found that advice and guidance for those not in the direst need was patchy, if not non-existent (Grove and Giraud-Saunders, 2003; Hoggarth and Smith, 2004). Funding for services was drawn from multiple sources and was unstable, while there was concern about standardization and quality.

Career guidance in schools and colleges was also patchy, while the service had unprotected status and was vulnerable to neglect (Mulvey, 2006: 17). This period also saw the number of career staff in the profession decline. The question of inadequate knowledge amongst guidance advisers in education or employment services thus arises, and the importance of training and continuous professional development that keeps pace with economic and labour market change is widely recognized (Hughes and Borbély-Pecze, 2012: 9). Interviewees questioned the quality of apprenticeships and whether these were adequately monitored. This has been an issue in both countries, although a comparison of policies concluded that the future looked brighter for Norway than for the United Kingdom (Payne, 2002). There is also evidence in our findings of gender segregation and stereotyping in job choices, which good careers advice and access to role models in gender-biased industries might help tackle (CIPD, 2015: 16).

Interviewees lamented a lack of meaningful work experience and jobreadiness, while some young people with higher qualifications said that they suffered from the presumption that they would go to university. Participation in higher education has risen sharply but is not necessarily a passport into well-paid, stable employment. The Chartered Institute of Personnel and Development, reporting on overqualification and skills mismatch in Europe, shows that expansion of higher education has been greater in the United Kingdom (43 per cent) and Norway (42 per cent) than in Europe as a whole (average 38 per cent; CIPD, 2015: 2). It reports that in 2010, 32 per cent of graduates were in non-graduate jobs in 
Norway, compared to 58.8 per cent in the United Kingdom (CIPD, 2015: 14). These figures beg the question as to whether or not the knowledge economy is providing the anticipated job opportunities for well-qualified youth.

Of young people surveyed in the United Kingdom, only 14 per cent had based their job choice on careers advice, while responses on future job choice suggested a narrow field of jobs, a big gap between aspiration and reality, and little understanding of the labour market and progress routes (CIPD, 2015: 8-9). In another survey more than 3000 14-19-yearolds revealed career aspirations that were reportedly unrealistic in the UK jobs market. The majority of respondents (68 per cent) planned to go to university, regardless of the limited supply of graduate jobs, and also had little idea of employer expectations (City \& Guilds, 2015: 100). It is likely that the drive to attend university often results from school, parent and peer pressure in the absence of viable alternatives of equal status and is pursued as an experience unrelated to employment prospects. It is also the case that with high rates of graduate entrants to the labour market some employers may now view a degree as a basic standard of education, regardless of the subject studied. This leads us to suggest that in the name of inclusivity, CEIAG should support young people at all qualification levels, providing the best labour market advice available.

We have highlighted the importance of CEIAG services to young people in transition from school to education or employment, identified good practice factors, and related these to policy in England and Norway. While Norway is found to have a better apprenticeship system than England and superior utilization of graduates in the labour market (CIPD, 2015; Payne, 2002), their new CEIAG policy initiatives indicate an awareness of room for improvement in a changing economic landscape. We advise awareness of the English experience and of the difference between identifying the necessary elements of an effective CEIAG policy and providing the infrastructure and resources to deliver it. Barriers that prevent successful implementation are now considered.

\section{BARRIERS TO EFFECTIVE CEIAG POLICIES}

An understanding of what good CEIAG services look like seems to be shared across Europe and internationally, so now we consider the barriers to their implementation in national policies. Bakke et al. (2017: 9), after describing Norway's commitment to improved CEIAG services, identify the following possible barriers: 
- Changes in political priorities in different sectors, impeding the implementation of agreed goals;

- Intersectoral coordination between sector-based missions, means and regulations may be extremely demanding;

- Discrepancy between expected actions according to agreed goals and necessary funding and capacity;

- Colliding regulations between sectors, complicating the enabling of changes and solutions; and

- Lack of political engagement and willingness to increase funding of guidance services.

These barriers are familiar in UK CEIAG services and stand as a lesson for Norwegian policymakers. Of the eight good-practice benchmarks developed in England (Holman, 2014: 7), the first - an embedded stable careers programme - remains elusive. Neoliberal policies, encompassing privatization, arms-length agencies, delegation and deregulation were introduced in the 1980s and have been supported ever since, throwing many public services into a long-term state of flux. The impact on CEIAG services and staff has been described by Deirdre Hughes: 'The career development profession has largely been left on the periphery of the careers experiment. . There are tensions yet to be resolved when it comes to a quasi-market experiment in careers work and the role of government' (Hughes, 2017: 1).

The need to establish a horizontal cross-departmental agenda, local partnerships and vertical multi-level governance to improve CEIAG policy faces entrenched obstacles, not least the historic distinctions between education and training and vocational and academic routes. CEIAG does not fit into one public policy silo in that it is relevant right across education, employment, health and welfare services. It also remains a candidate for chopping and changing, without the necessary public awareness and support to protect it. The Careers Alliance, a pressure group of CEIAG-friendly social partners, learning providers and other organizations, recommended the adoption of a protocol for interdepartmental collaboration on careers to avoid the present situation where three ministries and other public bodies are 'funding overlapping initiatives and yet still leave gaps in provision' (Herrmann and Hooley, 2015: 3).

Political commitment and resource allocation have failed to keep pace with the growing needs of individuals and the economy for professional CEIAG services. Government guidance to schools (Department for Education, 2017) reflects a sound policy that remains a challenge to implement. That 22000 self-governing schools in England will be able to develop a robust CEIAG strategy in line with rigorous guidance with no 
dedicated budget at a time of funding cuts, is doubtful. At national level, the now defunct employer-driven UK Commission for Employment and Skills produced more than 100 reports of research and studies, including some on career choice and providing career development and support through websites and new technologies. There are also the Careers and Enterprise Company, the National Careers Service for England and the Careers Development Institute providing online information, networking encouragement and training advice for career professionals. These organizations are unlikely to fill the gap left by an absence of advice and guidance at local level.

There are vocal advocates for a change in CEIAG policy in England. At European level, governments are challenged to: give higher priority to CEIAG; resource it sufficiently; create an education, careers and business knowledge triangle; embed career management skills; foster cooperation and collaboration across government departments; invest in good jobs, apprenticeships and work-related experiential learning; and transfer effective policies across European states (Hughes and Borbély-Pecze, 2012: 16). Before the United Kingdom's 2015 general election, the Careers Alliance presented a policy statement to political parties and the electorate, asserting that 'governments of all colours have failed to deliver an effective career support system for England' and identifying key elements for policy including a national strategy that connects activity in different ministerial departments and clarifies individual entitlement to career support and expected outcomes. The statement suggests that 'careers has suffered from a plethora of initiatives and too little strategy' (Herrmann and Hooley, 2015: 1-2).

\section{CONCLUSION}

We have made a case for improved CEIAG services in an effort to provide sufficient support for young people facing transition to employment and possible job insecurity. NEGOTIATE research findings have been cited that conclude that it is crucial for countries to build up their institutions to support young people, provide personal guidance, coordinate across national and local levels, and provide the necessary resources (NEGOTIATE, 2017).

The voices of interviewees have been used to illustrate perceived shortcomings in current systems, as well as some positive experiences. They provide examples of employment scarring from early decisions and broken work records; ill-informed advice and gender stereotyping; inadequate provision for those with physical and mental disability; the 
importance of work experience and gaining employability skills; the need for monitored, quality apprenticeships; CEIAG services for all young people regardless of their level of qualification; and the need to coordinate agencies in a personalized service.

They have also demonstrated the benefits that come when caseworkers are able to provide individualized support and to communicate well with the users, as in the case of Norway's Elin and the United Kingdom's Lulu. Good CEIAG policy and practice have been discussed, as have barriers that CEIAG policy is likely to face. As Norway continues its efforts to improve CEIAG services, we suggest that it be mindful of 20 years of failure in England to establish a stable, visible and embedded guidance system for young people entering the labour market. English policy on CEIAG services demonstrates a knowledge of what is required that is not matched by action.

General acknowledgement of an economic or social need may create a political imperative to develop policy that is not accompanied by the necessary resources, infrastructure or commitment for effective implementation. There is widespread recognition of the necessary conditions to deliver good CEIAG practice: cross-sector and partnership working; clear roles and accountability; consistency and stability; monitoring and quality assurance; with adequate resources including the supply of well-qualified career guidance professionals, who are experts on the labour market and routes into it. The service should be accessible to all, but personalized and targeted, using digital technologies blended with face-to-face advice and user involvement. Among the barriers that are faced in achieving effective CEIAG services, political commitment and adequate resourcing loom large.

We have considered the chequered history of CEIAG services in England once the Careers Service based on partnership was replaced by an unmonitored market system, patchy provision and a poorly managed and resourced Connexions service. The expectations now placed on education providers to deliver robust CEIAG services in partnership with employment advisers and employers can only continue to be disappointed given ongoing funding cuts and voluntarism.

At this critical time for Norwegian CEIAG services, the government would do well to learn lessons on how to avoid setting up services for failure. On the role of digitally driven career guidance, for example, Hooley et al. (2015: 52) suggest that 'Norway currently has the opportunity to address these issues in a more strategic way than many of the countries discussed in the case studies.' It can avoid an unruly and complex web of mixed provision and frequent changes in objectives and structures and understand that significant political commitment is necessary to ensure embedded, cross-sectoral, multi-level partnership service delivery. 
It is also important to remember that CEIAG, though important, is only one component of support to young people in transition from secondary education. Advisers cannot direct users to meaningful work experience and quality trainee, intern or apprenticeship programmes if they do not exist. It is a significant challenge to put in place effective transition systems, but the need to do so is growing ever greater. Consideration of UK and Norwegian CEIAG policy leads to the conclusion that mutual learning could take place if Norway learns from the United Kingdom's mistakes and establishes a world-class service, which could in turn inspire England to move its policy from rhetoric to reality.

\section{REFERENCES}

Ashworth K, Hardman J, Liu W, Maguire S and Middleton S (2001) Education maintenance allowance: The first year; a quantitative evaluation. Research Report no. 257 for the Department for Education and Skills. Nottingham, UK: DfES Publications.

Bakke GE, Nilsen AK, Tesdal S, Kjærgård R and Haug EH (2017) ICCDPP country paper: Norway. http://iccdpp2017.org/download/Country_paper_Norway_ ENG.pdf (accessed 29 November 2017).

Borbély-Pecze TB and Hutchinson J (2013) The youth guarantee and lifelong guidance. ELGPN Concept Note no. 4. http://www.elgpn.eu/publications/browse-by-lan guage/english/Borbely-Pecze_and_Hutchinson_Youth_Guarantee_concept_note _web2.pdf/at_download/file (accessed 10 June 2017).

Bridge Group (2011) Social Mobility Through Higher Education. London, UK: Bridge Group.

Career Management Quality Alliance (2017) A careers strategy that works for everyone: Position statement. http://matrixstandard.com/wp-content/uploads/2017/08/ CMQA-Position-Statement-August-2017.pdf (accessed 7 December 2017).

CIPD (2015) Over-qualification and skills mismatch in the graduate labour market. CIPD Policy Report. London, UK: Chartered Institute of Personnel and Development.

City \& Guilds (2015) Great Expectations: Teenagers' Career Aspirations Versus the Reality of the UK Jobs Market. London, UK: City and Guilds of London Institute.

Coldwell M, Trickey S, Holland MR and Smith P (2005) Bridging the gap? The role of transition advisers in the move from compulsory education. http://shura. shu.ac.uk/172/1/fulltext.pdf (accessed 4 December 2017).

Department for Education (2017) Career guidance and inspiration in schools: Statutory guidance for governing bodies, school leaders and school staff. London, UK: DfE.

Department for Education and Skills (2003) Information, advice and guidance for adults; the national policy framework and action plan. London, UK: DfES.

Dobson B, Hardman J, Maguire S, Middleton S, Allen T, Graham J, Hill E, Woodfield C and Maguire M (2003) Education maintenance allowance pilots for vulnerable young people and childcare pilots: Implementation and reported impacts 
in the first two years (2000-2001/2001-2002). Department for Education and Skills Research Report no. 470. Nottingham, UK: DfES Publications.

Drucker, P (1969) The Age of Discontinuity; Guidelines to our Changing Society. New York: Harper and Row.

ELGPN (2015) A report on the work of the ELGPN 2007-15. www.elgpn.eu/publica tions/browse-by-language/english/elgpn-summative report-2007-2015/ (accessed 20 June 2017).

ELGPN (2017) European Lifelong Guidance Policy Network website. http://www. elgpn.eu/about-us (accessed 12 December 2017).

Euroguidance (2014) Guidance systems in Norway. www.euroguidance-in-Europe/ national-guidance-systems/guidance (accessed 1 September 2017).

Grove B and Giraud-Saunders A (2003) Connecting with Connexions: The role of the personal adviser with young people with special educational and support needs. Support for Learning 18(1): 12-17.

Herrmann K and Hooley T (2015) Developing a world class career guidance system: A pre-election statement by the Careers Alliance. https://www.unionlearn.org.uk/. . . developing-world-class-career-guidance-system (accessed 10 September 2017).

Higginbotham S and Hughes D (2006) The future of professional career guidance: where next? CeGs Occasional Paper. Derby, UK: Centre for Guidance Studies.

Hoggarth L and Smith D (2004) Understanding the impact of Connexions on young people at risk. Department for Education and Skills Research Report no. 607. Nottingham, UK: DfES Publications.

Holman J (2014) Good career guidance. Report for the Gatsby Charitable Foundation. www.gatsby.org.uk//uploads/education/reports/pdf/gatsby-sir-john-holman-goo d-career-guidance-2014.pdf (accessed 9 May 2017).

Hooley T, Hutchinson J and Watts AG (2010) Enhancing choice? The role of technology in the career support market. UKCES Report. London, UK: UK Commission for Employment and Skills.

Hooley T, Matheson J and Watts AG (2014) Advancing ambitions: The role of career guidance in supporting social mobility. London, UK: Sutton Trust.

Hooley T, Shepherd C and Dodd V (2015) Get yourself connected: Conceptualising the role of digital technologies in Norwegian career guidance. http://hdl.handle. net/10545/579570 (accessed 12 December 2017).

Hughes D (2017) Careers work in England's schools: Politics, practices and prospects. British Journal of Guidance and Counselling. Epub ahead of print 4 July 2017. DOI: 10.1080/03069885.2017.1346234.

Hughes D and Borbély-Pecze TB (2012) Youth unemployment: A crisis in our midst: The role of lifelong guidance policies in addressing labour supply and demand. ELGPN Concept Note no. 2. http://www.elgpn.eu/publications/browse-by-langua ge/english/elgpn_concept_note2_youth_unemployment (accessed 10 June 2017).

Hughes S (2011) The Hughes Report. Report to the Prime Minister and the Deputy Prime Minister from the Advocate for Access to Education. https://assets.publ ishing.service.gov.uk/government/uploads/system/uploads/attachment_data/file/ 61218/education-advocate-report.pdf (accessed 7 June 2018).

ICCDPP (2017) Norway: developing a lifelong guidance system. http://iccdpp.org/ portfolio/norway-developing-a-lifelong-guidance-system/ (accessed 29 November 2017).

Maguire S and Maguire M (2004) Implementation of the education maintenance allowance pilots: The fourth year. Department for Education and Skills Research Report no. 540. Nottingham, UK: DfES. 
McCrone T, Gardiner C, Southcott C and Featherstone G (2010) Information, advice and guidance for young people. NFER Research Report. Slough, UK: National Foundation for Education Research.

McQuaid RW (2010) Theory of organizational partnerships - partnership advantages, disadvantages and success factors. In: Osborne SP (ed.) The New Public Governance: Critical Perspectives and Future Directions. Abingdon, UK: Routledge, pp. 125-46.

Mulvey MR (2006) Career guidance in England: Retrospect and prospect. British Journal of Guidance and Counselling 34(1): 13-30.

National Audit Office (2004) Connexions service advice and guidance for all young people. Report by the Comptroller and Auditor General. HC 484 (Session 2003-2004). London, UK: The Stationery Office.

NEGOTIATE (2017) Co-ordination of European strategies to tackle early job insecurity and youth unemployment: Lessons from a comparative study. NEGOTIATE Policy Brief no. 7. https://negotiate-research.eu/files/2017/09/NEGOTIATE_ POLICY_BRIEF_NO7_08_17.pdf (accessed 8 December 2017).

OECD (2002) OECD Review of Career Guidance Policies: Norway Country Note. http://www.oecd.org/edu/innovation-education/1937973.pdf (accessed 14 December 2017).

OECD (2004) Careers Guidance and Public Policy: Bridging the Gap. Paris: OECD.

OECD (2014) Skills Strategy: Norway. Executive Summary. Paris: OECD.

Ofsted (2013) Going in the right direction? Careers guidance in schools. School Survey Report no. 130114. Manchester, UK: Ofsted.

Oomen A and Plant P (2014) Early school leaving and lifelong guidance. ELGPN Concept Note no. 6. www.elgpn.eu/publications/browse-by-language/english//elg pn-concept-note-no.-6-early-school-leaving-and-lifelong-guidance (accessed 10 June 2017).

Payne J (2002) Reconstructing apprenticeships for the twenty-first century: Lessons from Norway and the UK. Research Papers in Education 17(3): 261-92.

Savickas M (2003) Advancing the career counselling profession: Objectives and strategies for the next decade. Career Development Quarterly 52(1): 87-96.

Social Exclusion Unit (1999) Bridging the gap: New opportunities for 16-18 year olds not in education, employment or training. Report no. 4405. London, UK: The Stationery Office.

Social Mobility and Child Poverty Commission (2013) State of the Nation 2013: Social Mobility and Child Poverty in Great Britain. London, UK: The Stationery Office.

Spernes K (2014) Skolens betydning for den lave andelen av ungdom med innvandrerbakgrunn i lærerutdanningen [The importance of school for the low share of youth with an immigrant background in teacher training]. Tidsskrift for ungdomsforskning 14(2): 3-27.

Sub-Committee on Education, Skills and the Economy (2016a) Careers education, information and guidance. Report HC 205. London, UK: The Stationery Office.

Sub-Committee on Education, Skills and the Economy (2016b) Careers education, information, advice and guidance. Government response to the first joint report of the business, innovation and skills and education committees of Session 2016-17. Report HC 757. London, UK: The Stationery Office.

Sultana RG (2012) Flexicurity: Implications for lifelong career guidance. ELGPN Concept Note no. 1. www.elgpn.eu/publications/browse-by-language/english/Sul tana_flexicurity_concept_note_web.pdf/(accessed 10 June 2017). 
UK Parliament (2016) Government inaction on careers provision failings is unacceptable. https://www.parliament.uk/business/committees/committees-a-z/commons-select/ education-skills-and-economy/news-parliament-2015/careers-advice-government -response-16-17/ (accessed 12 December 2017).

Watts AG (1996) Careers guidance and public policy. In: Law B, Killeen J, Kidd JM and Hawthorn R (eds) Rethinking Careers Education and Guidance. Abingdon, UK: Routledge, pp. 380-91.

Watts AG (2008) The partnership model for careers education and guidance: Rise, decline - and fall. Career Research and Development 20: 14-18.

Watts AG and Sultana R (2004) Career guidance policies in 37 countries: Contrasts and common themes. International Journal for Education and Vocational Guidance 4: 105-22. 